\title{
Szanse i zagrożenia sektora małych i średnich przedsiębiorstw wobec przystapienia Polski do Unii Europejskiej
}

\section{Wprowadzenie}

Integracja $\mathrm{z}$ Unią Europejską wprowadziła wiele zmian $\mathrm{w}$ dotychczasowych warunkach działania przedsiębiorstw [Karpińska-Mizielińska 2003]. Musiały one dostosować się do obowiązujących w UE norm i standardów nie tylko w celu eksportu swoich produktów na tenże rynek, ale także dla zapewnienia sobie możliwości sprzedaży na rynku polskim, który stał się częścią rynku europejskiego. Sytuacja ta wymusiła na podmiotach gospodarczych uruchomienie procesów adaptacyjnych do nowych warunków działania, a w konsekwencji ich restrukturyzację. Doświadczenia krajów, które weszły w skład Unii Europejskiej wskazują jednak, że integracja wiąże się z ponoszeniem przez podmioty gospodarcze znacznych kosztów, co w konsekwencji może się przyczyniać do osłabienia ich konkurencyjności. Dotyczy to zwłaszcza małych i średnich przedsiębiorstw. Przedstawiona sytuacja jest godna zainteresowania ze względu na fakt, że Polska jest członkiem Unii Europejskiej od maja 2004 roku, a polskie przedsiębiorstwa stały się pełnoprawnymi podmiotami tego rynku [Kowol 2002]. Oznacza to konieczność znajomości i stosowania przepisów obowiązujących w całej Wspólnocie. Biorąc pod uwage specyficzne cechy firm należących do sektora MSP oraz jego zdolność do generowania nowych miejsc pracy, można stwierdzić, że sektor ten odgrywa kluczową rolę w rozwoju gospodarczym Unii Europejskiej.

Małe i średnie przedsiębiorstwa, które stanowią podstawę gospodarki, są szczególnie narażone na liczne zmiany w otoczeniu biznesu, które wynikają $z$ restrukturyzacji gospodarki i akcesji do UE ${ }^{1}$. Musiały zostać uwzględnione ich specyficzne potrzeby. Dlatego też zarówno państwa kandydujące, jak i Unia

\footnotetext{
${ }^{1}$ „Rozszerzenie Unii Europejskiej. Czego mogą oczekiwać przedsiębiorstwa z nowych państw członkowskich? Pytania i odpowiedzi" Komisja Europejska, Dyrekcja Generalna do Spraw Przedsiębiorczości, maj 2003, s. 5-15.
} 
Europejska wprowadziły instrumenty mające na celu usprawnienie tego okresu przejściowego. Przyznana im pomoc jest przeznaczona na ożywienie współpracy gospodarczej, wdrażanie ustawodawstwa unijnego oraz wzmocnienie infrastruktury handlowej i instytucji wspierających przedsiębiorczość w nowych krajach członkowskich ${ }^{2}$.

\section{Zewnętrzne uwarunkowania przedsiębiorczości}

Przedsiębiorstwo może się rozwijać w określonych warunkach. Można wyróżnić cztery główne rodzaje otoczenia: otoczenie ekonomiczne, polityczne, techniczne i społeczne (tab. 1).

\section{Tabela 1}

Rodzaje otoczenia sektora MSP

\begin{tabular}{|l|l|}
\hline Rodzaj otoczenia & Elementy składowe \\
\hline Otoczenie ekonomiczne & $\begin{array}{l}\text { Popyt globalny, podział dochodu narodowego, system } \\
\text { funkcjonowania gospodarki narodowej, stopa inflacji, } \\
\text { poziom bezrobocia }\end{array}$ \\
\hline Otoczenie polityczne & $\begin{array}{l}\text { Monopole i praktyki restrykcyjne, rozmieszczenie prze- } \\
\text { mysłu, prawna ochrona konsumenta }\end{array}$ \\
\hline Otoczenie techniczne & Odkrycia naukowe, nowe technologie \\
\hline Otoczenie spoleczne & Rozmiary populacji, struktura wieku, wykształcenie \\
\hline
\end{tabular}

Źródło: J. Lichtarski: „Podstawy nauki o przedsiębiorstwie”, Wydawnictwo Akademii Ekonomicznej im. Oskara Langego we Wrocławiu, Wroclaw 2001, s. 184.

Otoczenie stanowi warunki zewnetrzne istnienia i rozwoju przedsiębiorstw. Klasyfikację uwarunkowań zewnętrznych można przeprowadzić uwzględniając trzy poziomy [Kwarcińska 2004]:

1) poziom świata:

- uwarunkowania związane z integracją oraz globalizacja,

- uwarunkowania wynikające $\mathrm{z}$ sytuacji międzynarodowej, np. umowy międzynarodowe, światowy cykl koniunkturalny;

2) poziom państwa:

- uwarunkowania prawne,

- uwarunkowania ekonomiczne (polityka fiskalna i monetarna),

- uwarunkowania społeczne (system wartości),

- uwarunkowania pozostałe (kulturowe, demograficzne);

${ }^{2}$ The Commission Staff Working Document on the Impact of Enlargement on Industry, SEC (2003) 234. 
3) poziom regionu:

- uwarunkowania związane $\mathrm{z}$ działalnością władz lokalnych (podatki i opłaty, polityka rozwoju regionu - por. rys. 1).

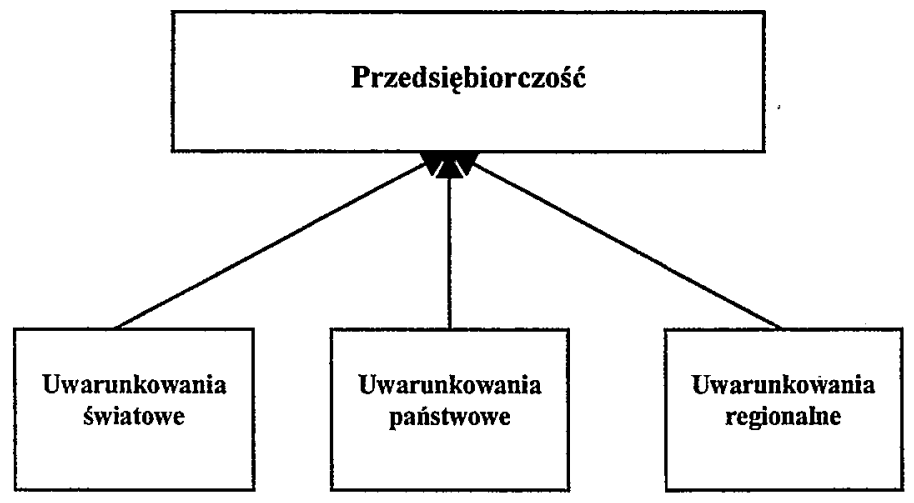

\section{Rysunek 1}

Wpływ uwarunkowań zewnętrznych na przedsiębiorczość

Źródło: A. Kwarcińska: „Uwarunkowania zewnętrzne jako szansa rozwoju przedsiębiorczości”. W: „Przedsiębiorczość stymulatorem rozwoju gospodarczego” pod red. J. Brdulaka i M. Kulikowskiego, Warszawa 2004, s. 18.

Uwarunkowania zewnętrzne tworzą złożony obraz otoczenia, w którym egzystuje przedsiębiorca i przedsiębiorstwo. Mogą one w znacznym stopniu decydować o rozwoju przedsiębiorczości. Ich korzystny układ może dynamizować przedsiębiorczość, stanowić szanse jej rozwoju, a także ułatwić rozwój i ekspansję na nowych rynkach.

\section{Charakterystyka sektora MSP w Polsce}

W latach 1990-2000 w Polsce powstało ponad 2,8 mln małych i średnich przedsiębiorstw [Grudzewski, Hejduk 2001]. W 2004 roku sektor MSP ocenia się na ok. 3,2 mln zarejestrowanych podmiotów gospodarczych, z czego ponad $1,8 \mathrm{mln}$ to firmy aktywne, wytwarzające prawie połowę $(49,9 \%)$ polskiego PKB. W sektorze tym znajduje zatrudnienie ok. 10,8 mln osób. MSP są integralnie związane $z$ gospodarką lokalna, pobudzają i wykorzystują przedsiębiorczość mieszkańców i aktywność miejscowych władz, przyczyniając się do rozwoju gospodarczego terenu, na którym działają [Bombol, Dąbrowska, Janoś-Kresło 2003]. 
Tabela 2

Liczba przedsiębiorstw w Polsce według REGON w latach 1991-2003

\begin{tabular}{|l|r|r|r|r|r|}
\hline \multirow{2}{*}{ Lata } & \multirow{2}{*}{$\begin{array}{l}\text { Przedsiębior- } \\
\text { stwa ogólem }\end{array}$} & \multicolumn{5}{|c|}{ Podział przedsiębiorstw pod względem liczby zatrudnionych } \\
\cline { 3 - 6 } & & \multicolumn{1}{|c|}{ MSP } & $0-5$ (mikro) & \multicolumn{1}{c|}{$0-50$} & $51-250$ \\
\hline 1991 & 502275 & 494211 & 375560 & 496436 & 24775 \\
\hline 1993 & 1988079 & 1980705 & 1812347 & 1957209 & 23496 \\
\hline 1994 & 2099577 & 2093148 & 1921151 & 2069930 & 23218 \\
\hline 1995 & 2301972 & 2294665 & 2109589 & 2270191 & 24474 \\
\hline 1996 & 2379949 & 2373484 & 2191892 & 2349422 & 24062 \\
\hline 1997 & 2552649 & 2546405 & 2359624 & 2251802 & 24603 \\
\hline 1998 & 2792697 & 2786462 & 2591499 & 2761010 & 25452 \\
\hline Lata & Przedsiębior- & MSP & $0-5$ (mikro) & $0-49$ & $50-249$ \\
\hline 1999 & 3013876 & 3007444 & 2865517 & 2978574 & 28870 \\
\hline 2000 & 3182577 & 3176161 & 3029859 & 3147059 & 29102 \\
\hline 2001 & 3374956 & 3368366 & 3206452 & 3337557 & 30809 \\
\hline 2002 & 3468218 & 3462775 & 3602411 & 3462775 & 28884 \\
\hline 2003 & 3518372 & 3513221 & 3350350 & 3484758 & 28463 \\
\hline
\end{tabular}

Źródlo: K. Wach, G. Wielgus: „Tendencje rozwojowe sektora malych i średnich przedsiębiorstw Polsce w latach 1991-2003”. W: „Przedsiębiorczość stymulatorem rozwoju gospodarczego" pod red. J. Brdulaka i M. Kulikowskiego, Warszawa 2004, s. 70.

\section{Tabela 3}

Przedsiębiorstwa zarejestrowane i aktywne w Polsce w latach 1991-2003

\begin{tabular}{|l|c|c|c|}
\hline Lata & $\begin{array}{c}\text { MSP zarejestrowane } \\
\text { (wg REGON) }\end{array}$ & $\begin{array}{c}\text { MSP aktywne } \\
\text { (wg szacunków GUS) }\end{array}$ & $\begin{array}{c}\text { Procentowy udział } \\
\text { aktywnych MSP }\end{array}$ \\
\hline 1991 & 492000 & b.d. & b.d. \\
\hline 1993 & 1980700 & b.d. & b.d. \\
\hline 1994 & 2294665 & 1110595 & $48,4 \%$ \\
\hline 1995 & 2093148 & 1136808 & $54,3 \%$ \\
\hline 1996 & 2373484 & 1340269 & $56,5 \%$ \\
\hline 1997 & 2546405 & 1580187 & $62,1 \%$ \\
\hline 1998 & 2786462 & 1722616 & $61,8 \%$ \\
\hline 1999 & 3007444 & 1816016 & $60,4 \%$ \\
\hline 2000 & 3176161 & 1763002 & $55,5 \%$ \\
\hline 2001 & 3368366 & 1654822 & $49,1 \%$ \\
\hline 2002 & 3462775 & b.d. & b.d. \\
\hline 2003 & 3513221 & b.d. & b.d. \\
\hline
\end{tabular}

Źródło: jak w tabeli 2. 
Oszacowanie rzeczywistej liczby małych i średnich przedsiębiorstw jest trudne. Rejestr REGON służy wprawdzie do ewidencji przedsiębiorstw działających w Polsce, jednakże ukazuje on jedynie liczbę przedsiębiorstw zarejestrowanych, a nie faktycznie działających, czyli aktywnych. Wynika to m.in. $\mathrm{z}$ faktu, że nieterminowo jest zgłaszane zaprzestanie aktywności gospodarczej przez przedsiębiorców, zwłaszcza tych drobnych.

Warto zauważyć, że liczba aktywnych MSP maleje od 1999 roku, przy jednoczesnym wzroście liczby przedsiębiorstw rejestrowanych (tab. 3).

\section{Czynniki mające wpływ na rozwój MSP}

Analizując zachowanie małych i średnich przedsiębiorstw, nie można dokonywać ich oceny na podstawie kryteriów przyjętych dla dużych organizacji. $\mathrm{Na}$ ich działalność mają wpływ inne czynniki. Istotną rolę odgrywa osoba właściciela, który najczęściej jest także menedżerem odpowiedzialnym za zarządzanie firmą. Przedsiębiorca to kluczowa postać $w$ przedsiębiorstwie, jest on głównym czynnikiem sprawczym i motorem postępu ekonomicznego [Sudoł 2002]. Analizując zachowania marketingowe małych i średnich firm, można powiedzieć, że na ich rozwój mają wpływ czynniki związane z osobą właściciela, tj.: wiek, wykształcenie, poprzednie miejsce pracy i zatrudnienie, ogólna filozofia biznesu, zarządzanie czasem. Te czynniki tworzą obraz przedsiębiorcy małej firmy.

\section{Szanse i zagrożenia na rynku Unii Europejskiej}

W celu sprawdzenia, jak polscy przedsiębiorcy postrzegają korzyści i zagrożenia funkcjonowania na rynku europejskim, zostały przeprowadzone badania $^{3}$. W. Karpińska-Mizielińska i T. Smuga zebrali informacje o 267 przedsiębiorstwach, wyniki ich badań zostały opublikowane w „Gospodarce Narodowej" $\mathrm{nr} 11-12 / 2003$. Badania zostały przeprowadzone w dwóch grupach przedsiębiorstw: eksporterów oraz celowo dobranych przedsiębiorstw $\mathrm{z}$ dwóch województw o zróżnicowanym poziomie rozwoju społeczno-ekonomicznego (pomorskie i podlaskie). Wypowiadając się na temat funkcjonowania przedsiębiorstw na rynku europejskim, respondenci wskazywali zarówno szanse, jak i zagrożenia. Wypowiedzi na ten temat cechowało znaczne rozproszenie (tab. 4).

\footnotetext{
${ }^{3}$ W. Karpińska-Mizielińska W., Smuga T., Bariery funkcjonowania małych i średnich przedsiębiorstw na jednolitym rynku europejskim w ocenie przedsiębiorców, Gospodarka Narodowa nr $11-12 / 2003$, s. 85.
} 
Tabela 4

Szanse i zagrożenia funkcjonowania MSP na rynku europejskim

\begin{tabular}{|c|c|c|c|c|c|c|}
\hline \multirow{2}{*}{ Kategorie odpowiedzi } & \multicolumn{2}{|c|}{ Ogólem } & \multirow{2}{*}{$\begin{array}{c}\text { Ekspor- } \\
\text { terzy }\end{array}$} & \multirow{2}{*}{ Regiony } & \multirow{2}{*}{ Małe } & \multirow{2}{*}{ Srednie } \\
\hline & liczba & $\%$ & & & & \\
\hline \multicolumn{7}{|c|}{ SZANSE } \\
\hline Zwiekszenie rynku zbytu & 95 & 35,6 & 35,2 & 37,3 & 35,9 & 35,2 \\
\hline $\begin{array}{l}\text { Nowe możliwości uzyskania } \\
\text { pomocy finansowej }\end{array}$ & 89 & 33,3 & 32,9 & 35,3 & 31,7 & 35,2 \\
\hline $\begin{array}{l}\text { Zwiększenie możliwości ko- } \\
\text { operacyjnych }\end{array}$ & 79 & 29,6 & 32,9 & 15,7 & 26,0 & 33,6 \\
\hline $\begin{array}{l}\text { Stabilizacja warunków działa- } \\
\text { nia }\end{array}$ & 60 & 22,5 & 24,5 & 7,8 & 19,7 & 25,6 \\
\hline $\begin{array}{l}\text { Zwiększenie dostępu do no- } \\
\text { wych technologii }\end{array}$ & 51 & 19,1 & 16,7 & 29,4 & 17,6 & 20,8 \\
\hline $\begin{array}{l}\text { Zwiększenie możliwości po- } \\
\text { zyskania kapitału }\end{array}$ & 37 & 13,8 & 14,4 & 11,8 & 12,7 & 15,2 \\
\hline Wzrost eksportu & 36 & 13,5 & 15,3 & 5,9 & 14,1 & 12,8 \\
\hline Wzrost popytu na wyroby & 32 & 12,0 & 11,1 & 15,7 & 12,7 & 11,2 \\
\hline $\begin{array}{l}\text { Zniesienie barier dostępu do } \\
\text { rynków zagranicznych }\end{array}$ & 30 & 11,2 & 12,0 & 13,7 & 9,9 & 12,8 \\
\hline $\begin{array}{l}\text { Zmniejszenie obciążeń podat- } \\
\text { kowych }\end{array}$ & 26 & 9,7 & 10,2 & 7,8 & 12,0 & 7,2 \\
\hline $\begin{array}{l}\text { Uzyskanie certyfikatów na } \\
\text { rynku UE }\end{array}$ & 25 & 9,4 & 8,9 & 7,8 & 9,2 & 9,6 \\
\hline $\begin{array}{l}\text { Zwiększenie możliwości wy- } \\
\text { boru dostawców }\end{array}$ & 25 & 9,4 & 9,7 & 3,9 & 9,2 & 9,6 \\
\hline Poprawa sytuacil finansowej & 24 & 9,0 & 6,5 & 19,6 & 11,3 & 5,6 \\
\hline Razem przedsiębiorstwa* & 267 & - & 216 & 51 & 142 & 125 \\
\hline \multicolumn{7}{|c|}{ ZAGROZ̈ENIA } \\
\hline Wzrost konkurencji na rynku & 181 & 67,8 & 63,0 & 88,2 & 67,6 & 68,0 \\
\hline Wzrost biurokracji & 91 & 34,1 & 34,3 & 33,3 & 36,6 & 31,2 \\
\hline Wzrost cen & 61 & 22,8 & 23,1 & 21,6 & 24,6 & 20,8 \\
\hline Wzrost importu & 60 & 22,5 & 22,7 & 21,6 & 21,8 & 23,2 \\
\hline Wzrost kosztów produkcji & 56 & 21,0 & 25,0 & 3,9 & 18,3 & 24,0 \\
\hline $\begin{array}{l}\text { Odpływ najlepszych fachow- } \\
\text { ców do UE }\end{array}$ & 48 & 18,0 & 17,6 & 19,6 & 18,3 & 17,6 \\
\hline $\begin{array}{l}\text { Obowiazywanie tych samych } \\
\text { zasad działania co przedsię- } \\
\text { biorców w UE }\end{array}$ & 30 & 11,2 & 11,6 & 9,8 & 10,6 & 12,0 \\
\hline Wzrost świadczeń socjalnych & 20 & 7,5 & 6,5 & 11,8 & 8,5 & 6,4 \\
\hline $\begin{array}{l}\text { Działalność przedsiębiorstwa } \\
\text { może stać się nieoplacalna }\end{array}$ & 19 & 7,1 & 6,9 & 5,9 & 7,7 & 5,6 \\
\hline Razem przedsiębiorstwa* & 267 & - & 216 & 51 & 142 & 125 \\
\hline
\end{tabular}

Źródło: opracowanie wlasne na podstawie: Karpińska-Mizjelińska W., Smuga T.: „Bariery funkcjonowania małych i średnich przedsiębiorstw na jednolitym rynku europejskim w ocenie przedsiębiorców", Gospodarka Narodowa nr 11-12/2003, s. 83-85.

*Dane przedstawione w tabeli nie sumują się do $100 \%$, gdyż respondenci odpowiadający na pytania w ankiecie mieli możliwość wyboru więcej niż jednej kategorii odpowiedzi. 
Analiza informacji zaprezentowanych w tabeli 4 pokazuje, że we wszystkich badanych grupach podmiotów wśród szans najczęściej wymieniano: zwiększenie rynku zbytu ( $35,6 \%$ badanych), nowe możliwości uzyskania pomocy finansowej $(33,3 \%)$, większe możliwości kooperacyjne $(29,6 \%)$, stabilizację warunków działania $(22,5 \%)$ oraz większe możliwości pozyskania kapitału $(19,1 \%)$. W próbie regionalnej znaczący był udział respondentów wskazujących na większy dostęp do nowych technologii $(29,4 \%)$.

Analizując zagrożenia można zauważyć, że respondenci byli bardziej jednomyślni. $\mathrm{Na}$ najważniejsze $\mathrm{z}$ wymienianych zagrożeń wskazywało blisko dwukrotnie więcej respondentów niż na pierwszą na liście korzyść (tab. 4). Najbardziej obawiano się wzrostu konkurencji na rynku (67,8\% badanych), a szczególnie silnie obawy te ujawniły się w badaniu regionalnym $(88,2 \%)$. Częstotliwość wskazań na tę kategorię była wielokrotnie wyższa niż na inne kategorie odpowiedzi. W grupie badanych zagrożeń jako istotne okazały się również: wzrost biurokracji $(34,1 \%)$, wzrost cen kosztów produkcji $(22,8 \%)$, nadmierny napływ towarów $\mathrm{z}$ importu $(22,5 \%)$, a także odpływ najlepszych fachowców do krajów UE (18,0\%). Analiza wypowiedzi badanych wskazuje, że przedsiębiorcy nie mieli jednak spójnego uporządkowanego obrazu zagrożeń dla przedsiębiorstw wynikających $\mathrm{z}$ otwarcia rynku.

Integracja z UE dla polskich przedsiębiorców oznacza przede wszystkim [Grudzewski, Hejduk 2001]:

- zniesienie barier celnych, a co za tym idzie - postawienie firm wobec konkurencji z dynamicznymi i silnymi europejskimi potentatami,

- zmuszenie przedsiębiorstw do zastosowania elementów euromarketingu w celu utrzymania lub poszerzenia swojej pozycji rynkowej,

- wyzwanie $\mathbf{i}$ walkę polskich firm $\mathrm{z}$ koncernami i firmami zarówno na dotychczasowym rynku wewnętrznym, jak i na pozostałych rynkach UE,

- wprowadzenie euroorientacji firmy.

Większość polskich przedsiębiorców jest zadowolona z przystapienia Polski do UE. W coraz większym stopniu prowadzą oni działalność w krajach tworzących europejski rynek wewnętrzny. Niepokojącym i złym symptomem jest to, że pewna część firm nie prowadzi żadnej działalności zagranicznej, ogranicza się tylko do rynku wewnętrznego. Trzeba stwierdzić, że takie przedsiębiorstwa mają make szanse na wybicie się i stworzenie silnej pozycji konkurencyjnej w przyszłości i skazane są na bankructwo. Jedynie elastyczne firmy, reagujące cały czas na rynek, a zwłaszcza na eurorynek, mają szanse nie tylko na przetrwanie, ale także na zaistnienie w innych krajach UE. 
Można zadać pytanie: jakiego rodzaju działania powinny podjąć przedsiębiorstwa, by zminimalizować ryzyko niepowodzenia na rynku europejskim? Odpowiedzią na to pytanie jest tabela 5 , w której zostały przedstawione wyniki badań dotyczących tego właśnie problemu [Karpińska-Mizielińska, Smuga $2003]^{4}$.

\section{Tabela 5}

Działania podejmowane w celu minimalizacji zagrożeń MSP na rynku europejskim

\begin{tabular}{|c|c|c|c|c|c|c|}
\hline \multirow{2}{*}{ Kategorie odpowiedzi } & \multicolumn{2}{|c|}{ Ogółem } & \multirow{2}{*}{$\begin{array}{l}\text { Ekspor- } \\
\text { terzy }\end{array}$} & \multirow[t]{2}{*}{ Regiony } & \multirow[t]{2}{*}{ Mate } & \multirow[t]{2}{*}{ Średnie } \\
\hline & liczba & $\%$ & & & & \\
\hline $\begin{array}{l}\text { Poprawa jakości } \\
\text { wyrobów }\end{array}$ & 83 & 31,1 & 33,3 & 21,6 & 26,8 & 36,0 \\
\hline $\begin{array}{l}\text { Obniżenie kosztów } \\
\text { działalności }\end{array}$ & 77 & 28,8 & 29,2 & 27,5 & 26,8 & 31,3 \\
\hline $\begin{array}{l}\text { Wprowadzenie } \\
\text { nowego produktu }\end{array}$ & 75 & 28,1 & 31,9 & 11,8 & 25,4 & 31,2 \\
\hline $\begin{array}{l}\text { Starania o certyfikaty, } \\
\text { normy i standardy UE }\end{array}$ & 64 & 24,0 & 28,2 & 5,9 & 14,9 & 34,4 \\
\hline $\begin{array}{l}\text { Modernizacja } \\
\text { majątku }\end{array}$ & 55 & 20,6 & 21,3 & 17,6 & 20,4 & 20,8 \\
\hline $\begin{array}{l}\text { Nawiazzanie kontak- } \\
\text { tów z partnerami } \\
\text { zagranicznymi }\end{array}$ & 51 & 19,1 & 22,7 & 3,9 & 16,2 & 22,4 \\
\hline $\begin{array}{l}\text { Wykorzystanie } \\
\text { Internetu }\end{array}$ & 37 & 13,9 & 15,7 & 5,9 & 12,7 & 15,2 \\
\hline $\begin{array}{l}\text { Usprawnienie } \\
\text { zarządzania }\end{array}$ & 31 & 11,6 & 11,1 & 13,7 & 9,9 & 13,6 \\
\hline $\begin{array}{l}\text { Uruchomienie nowej } \\
\text { działalności }\end{array}$ & 23 & 8,7 & 8,3 & 9,8 & 12,0 & 4,6 \\
\hline $\begin{array}{l}\text { Obniżka cen na pro- } \\
\text { dukowane wyroby }\end{array}$ & 19 & 7,1 & 6,9 & 7,8 & 6,3 & 8,0 \\
\hline $\begin{array}{l}\text { Komputeryzacja } \\
\text { przedsiębiorstwa }\end{array}$ & 19 & 7,1 & 6,0 & 11,8 & 5,6 & 8,8 \\
\hline $\begin{array}{l}\text { Zmiany w strukturze } \\
\text { organizacyjnej }\end{array}$ & 19 & 7,1 & 6,9 & 7,8 & 5,6 & 8,8 \\
\hline $\begin{array}{l}\text { Razem przedsiębior- } \\
\text { stwa }\end{array}$ & 216 & - & 216 & 51 & 142 & 125 \\
\hline
\end{tabular}

Źródło: jak w tabeli 4.

${ }^{4}$ W. Karpińska-Mizielińska, T. Smuga: „Bariery funkcjonowania...”, op. cit., s. 84-85. 
Można zauważyć, że wśród najczęstszych inicjatyw podejmowanych przez badanych przedsiębiorców znalazły się takie, których efektem może być wzmocnienie pozycji przedsiębiorstwa na rynku zagranicznym, czyli: poprawa jakości wyrobów $(31,1 \%$ badanych), wprowadzenie nowego produktu $(28,1 \%)$, obniżenie kosztów działalności $(28,8 \%)$, modernizacja majątku (20,6\%). Istotne również było spełnienie norm i standardów UE (24,0\%), uzyskanie niezbędnych w tym celu certyfikatów oraz nawiązanie kontaktów z partnerami zagranicznymi $(19,1 \%)$. Zarówno lista tych działań, jak i hierarchia w przedsiębiorstwach małych i średnich były zbliżone, $\mathrm{z}$ tym jednak, że przedsiębiorcy średni częściej podejmowali starania o certyfikaty - różnica o blisko 20 punktów proc. W próbie regionalnej istotne znaczenie miały również usprawnienie zarządzania (ok. 14\% wypowiedzi) oraz komputeryzacja (12\%). Najrzadziej natomiast wymieniane przez respondentów inicjatywy (poniżej 2\% wskazań) to: wykorzystanie wyników prac badawczo-rozwojowych, pozyskanie zagranicznego inwestora, utworzenie przedstawicielstwa za granicą oraz restrukturyzacja finansowa przedsiębiorstwa.

Integracja z Unią Europejską oraz liberalizacja wymiany handlowej z zagranicą spowodowały konieczność szybkiej poprawy kondycji oraz konkurencyjności polskich przedsiębiorstw. Aby osiągnąć wyższy poziom zdolności konkurowania oraz pełnić funkcję aktywizującą wzrost gospodarczy i czynnik ograniczający bezrobocie, polski sektor MSP wymaga odpowiednich nakładów inwestycyjnych.

Przedsiębiorcy wskazali również czynniki, które powinny być spełnione, aby polskie przedsiębiorstwa mogły odnieść sukcesy na rynkach zagranicznych [Karpińska-Mizielińska, Smuga 2003]. Odpowiedzi badanych prezentuje tabela $6^{5}$.

Wymieniane przez badanych przedsiębiorców czynniki zapewniające sukces na rynku europejskim były znacznie rozproszone. Znalazły się wśród nich zarówno przedsięwzięcia o charakterze mikroekonomicznym (obniżenie kosztów produkcji i pracy, powiązanie kapitałowe z partnerem zagranicznym, szeroka promocja i reklama, szybkie reagowanie na zmieniającą się sytuację na rynku, wdrożenie innowacji produktowych, wysoka jakość wyrobów), jak i makroekonomicznym (dostęp do środków pomocy publicznej, zwiększenie dostępu do kredytów, osłabienie kursu złotego).

Można zauważyć, że zmiennym mikroekonomicznym przypisywano rolę decydującą. Wskazania na poszczególne kategorie odpowiedzi znacznie różnicowały wielkość przedsiębiorstwa - dla podmiotów średnich większe znaczenie miały powiązanie kapitałowe $z$ partnerem zagranicznym (36\%), spełnienie

${ }^{5}$ W. Karpińska-Mizielińska, T. Smuga: „Bariery funkcjonowania...”, op. cit., s. 86-87. 
Tabela 6

Czynniki zapewniające sukces przedsiębiorstwa na rynku europejskim

\begin{tabular}{|c|c|c|c|c|c|c|}
\hline \multirow{2}{*}{ Kategorie odpowiedzi } & \multicolumn{2}{|c|}{ Ogólem } & \multirow{2}{*}{$\begin{array}{l}\text { Ekspor- } \\
\text { terzy }\end{array}$} & \multirow{2}{*}{ Regiony } & \multirow{2}{*}{ Małe } & \multirow{2}{*}{ Srednie } \\
\hline & liczba & $\%$ & & & & \\
\hline $\begin{array}{l}\text { Obniżenie kosztów } \\
\text { produkcji i pracy }\end{array}$ & 88 & 33,0 & 34,3 & 27,5 & 28,2 & 38,4 \\
\hline $\begin{array}{l}\text { Powiazanie kapitałowe } \\
\text { z partnerem zagranicz- } \\
\text { nym }\end{array}$ & 86 & 32,2 & 32,9 & 29,4 & 28,9 & 36,0 \\
\hline $\begin{array}{l}\text { Dostęp do środków w } \\
\text { ramach pomocy pań- } \\
\text { stwa }\end{array}$ & 73 & 27,3 & 29,2 & 15,7 & 29,6 & 24,8 \\
\hline $\begin{array}{l}\text { Szeroka promocja i } \\
\text { reklama }\end{array}$ & 54 & 20,2 & 21,8 & 5,9 & 21,8 & 18,4 \\
\hline $\begin{array}{l}\text { Szybkie reagowanie na } \\
\text { zmieniającą się sytu- } \\
\text { ację na rynku }\end{array}$ & 50 & 18,7 & 18,5 & 19,6 & 20,4 & 16,8 \\
\hline $\begin{array}{l}\text { Spełnienie norm i stan- } \\
\text { dardów UE }\end{array}$ & 47 & 17,6 & 18,1 & 7,8 & 12,7 & 23,2 \\
\hline $\begin{array}{l}\text { Wdrożenie innowacji } \\
\text { produktowych }\end{array}$ & 46 & 17,2 & 18,5 & 11,8 & 16,2 & 18,4 \\
\hline $\begin{array}{l}\text { Zwiększenie dostępu } \\
\text { do kredytów }\end{array}$ & 44 & 16,5 & 17,1 & 13,7 & 21,1 & 11,2 \\
\hline $\begin{array}{l}\text { Wysoka jakość wyro- } \\
\text { bów }\end{array}$ & 41 & 15,4 & 18,0 & 5,9 & 15,5 & 15,2 \\
\hline $\begin{array}{l}\text { Aktywne konkurowanie } \\
\text { na rynkach zagranicz- } \\
\text { nych }\end{array}$ & 32 & 12,0 & 11,6 & 13,7 & 14,1 & 9,6 \\
\hline Elastyczne zarządzanie & 26 & 9,7 & 7,9 & 17,6 & 13,4 & 5,6 \\
\hline $\begin{array}{l}\text { Większy dostęp do } \\
\text { nowoczesnych techno- } \\
\text { logii }\end{array}$ & 25 & 9,4 & 9,7 & 7,8 & 7,7 & 11,2 \\
\hline $\begin{array}{l}\text { Osłabienie kursu } \\
\text { złotego }\end{array}$ & 24 & 9,0 & 9,3 & - & 9,2 & 8,8 \\
\hline $\begin{array}{l}\text { Szerszy dostęp do } \\
\text { informacji }\end{array}$ & 22 & 8,2 & 8,3 & 9,8 & 9,2 & 7,2 \\
\hline $\begin{array}{l}\text { Razem } \\
\text { przedsiębiorstwa }\end{array}$ & 267 & - & 102 & 51 & 142 & 125 \\
\hline
\end{tabular}

Źródło: jak w tabeli 4.

norm i standardów UE $(23,2 \%)$ oraz obniżenie kosztów produkcji i pracy $(38,4 \%)$, natomiast dla małych dostęp do środków pomocy państwa $(29,6 \%)$, wysoka jakość wyrobów $(15,5 \%)$ oraz szeroka promocja i reklama $(21,8 \%)$. 
Rozwój przedsiębiorczości w Polsce napotyka na swojej drodze wiele barier [Hybel 2003]. Do najważniejszych z nich można zaliczyć: bariery finansowe, rynkowe, prawne, polityczne instytucjonalne oraz społeczne. Bariera finansowa polega na szczupłości własnych zasobów finansowych i trudności w pozyskaniu środków finansowych $\mathrm{z}$ zewnątrz. Bariery rynkowe są związane $\mathrm{z}$ wahaniami koniunktury gospodarczej, które wyrażają się spadkiem dochodów realnych ludności, obniżeniem rentowności przedsiębiorstw oraz zmniejszeniem tempa wzrostu inwestycji.

\section{Podsumowanie}

Rozszerzenie UE oznacza nowe warunki działalności przedsiębiorstw [Grudzewski, Miązek, Skrobisz 2001]. Po zniesieniu barier polskie firmy uzyskały dostęp do rynku UE, ale pociagnęło to też za sobą pewne konsekwencje. Dla jednych pojawiły się ogromne szanse, dla innych zagrożenia. Nie wszystkie przedsiębiorstwa odczuły zmiany jednakowo. Jedno jest pewne - polskie firmy muszą stać się konkurencyjne dla przedsiębiorstw unijnych. Przedsiębiorcy polscy poruszają się teraz po skomplikowanym prawodawstwie unijnym, wielu nowych przepisach. Trzeba zdobywać nowe, mocno nasycone już rynki zbytu oraz konkurować z przedsiębiorstwami zamożniejszymi i mającymi większe doświadczenie w operowaniu na wspólnym, europejskim rynku.

Przytoczone wyniki badań potwierdzily ${ }^{6}$, że w opinii przedsiębiorców z sektora MSP integracja z UE przyniosła korzyści (zniesienie barier i ograniczeń), ale i zagrożenia. Szanse pojawiły się przede wszystkim dla podmiotów aktywnych, dla których likwidacja granic otworzyła nowe możliwości ekspansji - zwiększenie rynku zbytu, zwiększenie dostępu do nowych technologii, zwiększenie możliwości pozyskania kapitału. Przedsiębiorcy powinni wykorzystać możliwości nowych rynków i zdobyć na nich bazę podstawowych klientów. Jednak, aby ich utrzymać, przedsiębiorcy muszą zapewnić im jakość, niezawodność i obsługę na poziomie co najmniej równym ofercie konkurencji - w przeciwnym wypadku trudno będzie im się długo utrzymać na rynku pełnym ostrej konkurencji.

Integracja z Unią Europejską zwiększyła mobilność siły roboczej, co ułatwia wymianę pracowników. Aby obawy przedsiębiorców, że najlepsi fachowcy odpłyną do krajów Unii nie potwierdziły się, należy inwestować we własnych pracowników. Na zatrzymanie dobrych pracowników duży wpływ mają

${ }^{6}$ Ibidem. 
nie tylko płace i świadczenia, ale ważne są też czynniki niematerialne, takie jak szkolenia, dowody uznania i zakres odpowiedzialności.

Z przytoczonych badań wynika, że polscy przedsiębiorcy duże szanse widzą także w większym dostępie do nowych technologii. Inwestycje w technologie sa jak najbardziej wskazane, jednak powinny być one przeprowadzone rozsądnie. Systemy zarządzania kontaktami z klientem, systemy zarządzania sprzedażą $\mathrm{i}$ inne systemy informatyczne mogą przynieść korzyści, ale tylko pod warunkiem, że zostaną efektywnie wykorzystane. Nie należy inwestować $\mathrm{w}$ informatykę, zaniedbując szkolenie personelu w zakresie jej użycia oraz zapominając o odpowiednim przystosowaniu procesów gospodarczych i struktury organizacyjnej.

Przedsiębiorcy powinni być również świadomi, że samo spełnienie wymagań unijnych nie oznacza gotowości do sprostania konkurencji na rynku UE. Należy stale aktualizować wiedzę o wymaganiach operacyjnych i warunkach działania.

\section{Literatura}

BOMBOL M., DĄBROWSKA A., JANOŚ-KRESŁO M., Możliwości rozwoju małych i średnich przedsiębiorstw w Polsce - Sympozjum Kolegium Zarządzania i finansów SGH nt. „Ekonomiczne instrumenty ożywienia gospodarki w Polsce”, 2003.

GRUDZEWSKI W.M., HEJDUK I.K., Konkurencyjność przedsiębiorstw z Europy Środkowej na rynku europejskim, Ekonomika i Organizacja Przedsiębiorstwa", nr 9/2001.

GRUDZEWSKI W.M., MIAZZEK P., SKROBISZ M., Szanse i zagrożenia polskich przedsiębiorstw w Unii Europejskiej, „Ekonomika i Organizacja Przedsiębiorstwa”, 4/2001.

HYBEL J., Ekonomiczne uwarunkowania rozwoju rynku pracy w Polsce w perspektywie integracji z Unią Europejska, Wydaw. SGGW, Warszawa 2003.

KARPIŃSKA-MIZIELIŃSKA W., SMUGA T., Bariery funkcjonowania małych i średnich przedsiębiorstw na jednolitym rynku europejskim w ocenie przedsiębiorców, Gospodarka Narodowa nr 11-12/2003.

KOWOL A., Polityka Unii Europejskiej wobec małych i średnich przedsiębiorstw. Dotychczasowy rozwój i wyzwania na przyszłość, 2002.

http://www.exporter.pl/linki/linkz_ue_msp.html

KRAJEWSKI K., Przedsiębiorczość w Polsce w perspektywie integracji z Unią Europejska, Decydent nr 6/34, 2002.06.19.

KWARCIŃSKA A., Uwarunkowania zewnętrzne jako szansa rozwoju przedsiębiorczości. W: Przedsiębiorczość stymulatorem rozwoju gospodarczego pod red. J. Brdulaka i M. Kulikowskiego, Warszawa 2004.

LICHTARSKI J., Podstawy nauki o przedsiębiorstwie, Wydaw. Akademii Ekonomicznej im. Oskara Langego we Wrocławiu, Wrocław 2001. 
Rozszerzenie Unii Europejskiej. Czego moga oczekiwać przedsiębiorstwa $\mathrm{z}$ nowych państw członkowskich? Pytania i odpowiedzi, „Komisja Europejska, Dyrekcja Generalna do Spraw Przedsiębiorczości", maj 2003.

The Commission Staff Working Document on the Impact of Enlargement on Industry, SEC (2003).

SUDOŁ S., Przedsiębiorstwo. Podstawy nauki o przedsiębiorstwie. Teoria i praktyka zarządzania, Toruń 2002, wyd. II.

WACH K., WIELGUS G., Tendencje rozwojowe sektora małych i średnich przedsiębiorstw Polsce w latach 1991-2003. W: „Przedsiębiorczość stymulatorem rozwoju gospodarczego" pod red. J. Brdulaka i M. Kulikowskiego, Warszawa 2004.

\section{Chances and Threats of Small and Medium Enterprises Sector in Poland towards Joining European Union}

\section{Abstract}

The process of integration with European Union means lots of changes in the functioning conditions of enterprises. They must adjust to norms and standards that are obligatory in EU. Polish market became a part of uniform European market. This situation forced economic entities to start adaptation processes to new conditions.

Small and medium enterprises, that are the basis of economy, are particularly sensitive for changes in business environment. Their special needs should be taken into consideration.

Majority of Polish entrepreneurs are satisfied with joining European Union. They lead business with countries that are members of EU. 